Buletin JSJ, 3 (1), 2021, 1-7

Available online di: http://ejournal-balitbang.kkp.go.id/index.php/JSJ/index

\title{
PENGGUNAAN KELAPA SEBAGAI PAKAN PADA BUDIDAYA Cherax quadricarinatus TERHADAP PERFORMA PERTUMBUHAN
}

\section{USE OF COCONUT AS FEED IN CULTIVATION OF Cherax quadricarinatus ON GROWTH PERFORMANCE}

\author{
Ernawati ${ }^{1}$, Mohammad Sayuti ${ }^{2}$, Imran $^{3}$ \\ ${ }^{1}$ Prodi Teknik Budidaya Perikanan, Politeknik Kelautan dan Perikanan Sorong \\ Jl. Tanjung Kasuari Kelurahan Suprau, Sorong, Papua Barat, 98411 \\ ${ }^{2}$ Politeknik Ahli Usaha Perikanan, Jakarta \\ Jl. Aup Bar. Jl. Raya Pasar Minggu, RT.1/RW.9, Jati Padang, Kec. Ps. Minggu, Kota Jakarta \\ Selatan, Daerah Khusus lbukota Jakarta 12520 \\ ${ }^{3} J u r u s a n$ Pertanian Politeknik Pembangunan Pertanian Manokwari \\ JI. SPMA Reremi, Manokwari, Papua Barat, 98312
}

Email: ernawati@polikpsorong.ac.id, mohsayut@gmail.com,.Imran_hkms@yahoo.com,

\begin{abstract}
ABSTRAK
Komoditas budidaya Cherax semakin meningkat karena memiliki ketahanan tubuh tinggi, mudah dibudidayakan, dapat dikonsumsi dan dijadikan sebagai krustacea hias. Penelitian ini bertujuan untuk mengetahui pengaruh pakan berbeda terhadap pertumbuhan panjang dan bobot tubuh serta kelangsungan hidup lobster air tawar (Cherax quadricarinatus). Wadah penelitian menggunakan akuarium berukuran $60 \times 40 \times 40 \mathrm{~cm}$ yang dilengkapi peralatan aerasi. Metode penelitian menggunakan rancangan acak lengkap (RAL) dengan 3 perlakuan yaitu C1: Pakan Pellet, C2: Pakan Kelapa dan C3 : Pellet+Kelapa dan masing-masing 3 kali ulangan. Penelitian tersebut memberikan pengaruh terhadap pertumbuhan bobot dan panjang tubuh namun tidak berpengaruh terhadap kelangsungan hidup lobster air tawar. Pertumbuhan bobot tertinggi diperoleh pada perlakuan C3 yaitu sebesar 4.400 gram/ekor, panjang tertinggi pada perlakuan C2 yaitu sebesar $1.220 \mathrm{~cm} /$ ekor dan kelangsungan hidup tertinggi yaitu pada perlakuan C2 dan C3 yaitu masing-masing $86,67 \%$.
\end{abstract}

Kata kunci : cherax; kelangsungan hidup; kelapa; pellet

\begin{abstract}
Cherax cultivation commodities are increasing because they have high body resistance, are easy to cultivate, can be consumed and used as ornamental crustaceans. This study aims to determine the effect of different feeds on growth in length and body weight and survival of freshwater crayfish

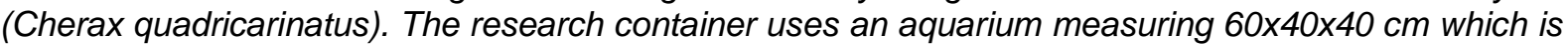
equipped with aeration equipment. The research method used a completely randomized design (CRD) with 3 treatments, namely C1: Pellet Feed, C2: Coconut Feed and C3: Pellet+Coconut and each replicated 3 times. The study had an effect on the growth of body weight and length but had no effect on the survival of freshwater crayfish. The highest weight growth was obtained in the C3 treatment, which was 4,400 grams/head, the highest length in the C2 treatment was 1,220 cm/head and the highest survival was in the C2 and C3 treatments, which were $86.67 \%$ respectively.
\end{abstract}

Keywords : cherax; coconut; survival; pellets

\section{PENDAHULUAN}

Budidaya lobster air tawar semakin banyak dikembangkan karena lebih mudah dibudidayakan dan harganya ekonomis. Salah satu jenis lobster air tawar yang hingga saat ini banyak dikembangkan yaitu Cherax quadricarinatus atau sering disebut red claw. Cherax ini berkembang sangat pesat karena memiliki ketahanan tubuh yang tinggi terhadap 
Buletin JSJ, 3 (1), 2021, 1-7

Available online di: http://ejournal-balitbang.kkp.go.id/index.php/JSJ/index

perubahan kualitas air, pola makannya lebih fleksibel (Karplus et al., 2001) dan pertumbuhannya lebih cepat (Wickins \& Lee, 2002). Dalam pengembangan red claw (Rodríguez-Canto et al., 2002) menyatakan bahwa budidaya sistem sirkulasi tertutup menghasilkan pertumbuhan yang lambat. Pertumbuhan lambat juga dipengaruhi oleh padat tebar yang tinggi dan pakan yang tidak sesuai dengan kebutuhan hewan tersebut. (Rodríguez-Canto et al., 2002).

Salah satu upaya yang dilakukan dalam mengatasi hal tersebut yaitu pemberian pakan yang memiliki kandungan nutrisi tinggi. Penggunaan pakan bernutrisi dapat menghasilkan pertumbuhan yang optimal. Jenis pakan tersebut dapat berasal dari pakan alami (Ernawati \& Hamsir, 2019) dan buatan (Kakam et al., 2008). Pakan pellet merupakan jenis pakan buatan yang mengandung kandungan nutrisi lengkap karena diproses dari berbagai jenis bahan dalam jumlah banyak (Zonneveld et al., 1991). Namun pada kenyataannya, pakan tersebut membutuhkan biaya yang lebih besar. Oleh karena, pada percobaan penelitian ini digunakan kelapa sebagai salah satu pakan bernutrisi yang mudah diperoleh dan biaya lebih ekonomis.

Kelapa merupakan salah satu bahan nabati yang mudah diperoleh dan harganya lebih ekonomis. Selain itu, dagingnya memiliki kandungan zat bioktif berupa asam fenolik dan flavonoid yang dapat mempengaruhi aktivitas antioksidan (Ngampeerapong \& Chavasit, 2019). (Kwon et al., 1996) melaporkan bahwa kandungan nutrisi daging kelapa yang dihilangkan lemaknya memiliki fraksi protein utama $40 \%$, albumin $21 \%$, glutelin-1 $14,4 \%$, glutelin-2 4,8\% dan fraksi prolamin 3,3\%. Penggunaan daging atau buah kelapa sebagai pakan tambahan telah diujicobakan oleh (Lengka \& Kolopita, 2013) khususnya pada induk untuk mempercepat kematangan gonad. Berdasarkan referensi tersebut penulis melakukan penelitian ini untuk mengetahui pengaruh pakan berbeda terhadap pertumbuhan dan kelangsungan hidup benih Cherax quadricarinatus.

\section{BAHAN DAN METODE}

\section{Metode Kerja}

Alat dan bahan yang digunakan yaitu akuarium, timbangan digital, mistar, baskom, pipa paralon, serok, blower, selang dan batu aerasi, buah kelapa, talenan, pisau/parang pakan pellet, daun kelapa, thermometer, $\mathrm{pH}$ meter, $\mathrm{DO}$ meter dan benih cherax berukuran berat $0,017 \mathrm{~g}$ dan panjang $0,8 \mathrm{~cm}$.

Penelitian dilakukan secara eksprimental dengan metode Rancangan Acak Lengkap (RAL)

yang terdiri dari 3 perlakuan dan 4 kali ulangan. Berikut metode penelitian yang digunakan yaitu :

Perlakuan C1: Pellet

Perlakuan C2 : Buah Kelapa

Perlakuan C3 : Pellet + Buah Kelapa

Benih Cherax dipelihara di dalam akuarium berukuran $60 \times 40 \times 40 \mathrm{~cm}$ sebanyak 50 ekor/ akuarium. Pemeliharaan tersebut dilakukan selama 28 hari. Pakan diberikan setiap hari dua kali sehari yaitu pagi dan sore hari dengan dosis $5 \%$ dari biomassa.

Pengumpulan data dilakukan secara langsung dengan cara sampling pada tiap-tiap wadah pemeliharaan setiap minggu. Jumlah sampel yang diukur sebanyak $10 \%$ dari total benih Cherax yang dipelihara. Pengukuran kelangsungan hidup dan laju pertumbuhan dilakukan pada awal dan akhir pemeliharaan

\section{Parameter Pengamatan}

Laju pertumbuhan bobot rata-rata harian dihitung dengan menggunakan rumus Huisman (1976) :

$$
S G R=\frac{W t-W o}{t} \times 100 \%
$$


Buletin JSJ, 3 (1), 2021, 1-7

Available online di: http://ejournal-balitbang.kkp.go.id/index.php/JSJ/index

Keterangan :

SGR = laju pertumbuhan bobot rata-rata harian

$\mathrm{Wt} \quad=$ bobot rata-rata individu pada akhir percobaan $(\mathrm{g})$

Wo = bobot rata-rata individu pada akhir percobaan $(\mathrm{g})$

$\mathrm{t} \quad=$ lama Pemeliharaan (hari)

Pertambahan panjang tubuh mutlak dihitung dengan menggunakan rumus Effendie (1979), sebagai berikut :

Keterangan :

$$
L=L t-L o
$$

$\mathrm{L} \quad=$ pertumbuhan panjang $(\mathrm{cm})$

Lt $\quad=$ panjang tubuh rata-rata pada akhir percobaan $(\mathrm{cm})$

Lo $\quad=$ panjang tubuh rata-rata pada awal percobaan $(\mathrm{cm})$

Tingkat kelangsungan hidup larva ikan nila salin dihitung menggunakan rumus (Supito et al., 1998):

$$
S R=\frac{\mathrm{Nt}}{\mathrm{No}} \quad 100 \%
$$

Keterangan :

$\mathrm{SR} \quad=$ tingkat sintasan (\%)

No = jumlah individu awal pemeliharaan (ekor)

$\mathrm{Nt} \quad=$ jumlah individu akhir penelitian (ekor)

\section{Analisis Data}

Data pertumbuhan dan kelangsungan hidup dianalisis secara statistik menggunakan sidik ragam (Anova). Apabila hasilnya berbeda nyata, maka dilanjutkan dengan uji Tuckey. Analisis data dilakukan dengan menggunakan SPSS versi 22.0. Sedangkan data kualitatif berupa kualitas air dianalisis secara deskriptif.

\section{HASIL DAN PEMBAHASAN}

Lobster merupakan salah satu jenis hewan akuatik dari kelompok crustacea yang memiliki kebiasaan hidup lebih aktif pada malam hari dan selalu melakukan pergantian kulit (moulting). Pergantian kulit biasanya terjadi setiap 10 hari sekali pada fase benih. Hal tersebut terjadi untuk meningkatkan pertumbuhannya. Hasil analisis ragam (ANOVA) pada pertumbuhan panjang, bobot tubuh dan kelangsungan hidup benih Cherax quadricarinatus selama penelitian dapat dilihat pada tabel 1.

Tabel 1. Hasil Analisis Ragam (ANOVA) Pertumbuhan dan Kelangsungan Hidup Cherax quadricarinatus

\begin{tabular}{lccccc}
\hline Dependent Variable & $\begin{array}{c}\text { Sum of } \\
\text { squares }\end{array}$ & df & $\begin{array}{c}\text { Mean } \\
\text { Square }\end{array}$ & F & Sig. \\
\hline Bobot & & & & & \\
Perlakuan & 3,662 & 2 & 1,831 & 11,771 & $0,008^{*}$ \\
Galat & 0,933 & 6 & 0,156 & & \\
Total & 4,596 & 8 & & & \\
\hline Panjang & & & & & \\
Perlakuan & 0,018 & 2 & 0,009 & 11,824 & \\
Galat & 0,005 & 6 & 0,001 & & \\
Total & 0,022 & 8 & & & \\
\hline
\end{tabular}


Buletin JSJ, 3 (1), 2021, 1-7

Available online di: http://ejournal-balitbang.kkp.go.id/index.php/JSJ/index

\begin{tabular}{lllcll}
\hline Kelangsungan Hidup & & & & & \\
Perlakuan & 43,556 & 2 & 21,778 & 2,882 & 0,133 \\
Galat & 45,333 & 6 & 7,556 & & \\
Total & 88,889 & 8 & & & \\
\hline
\end{tabular}

Keterangan : * Berpengaruh nyata $(p<0,05)$

Tabel 1. memperlihatkan bahwa penggunaan pakan kelapa dan pellet berpengaruh nyata terhadap pertumbuhan panjang dan bobot tubuh tapi tidak berpengaruh nyata terhadap kelangsungan hidup Cherax quadricarinatus. Penggunaan pakan pellet dan kelapa pada percobaan penelitian ini mampu meningkatkan pertumbuhan dan kelangsungan hidup hewan uji. Hal ini diduga bahwa kandungan nutrisi pakan tersebut mampu mencukupi kebutuhan benih Cherax. Selain itu, cherax memiliki kebiasaan makan berbagai jenis pakan (omnivora) sehingga mampu mengurangi kanibalisme. Taufiq et al., (2016) menyatakan bahwa bahan-bahan yang dapat termakan oleh cherax berupa kacang-kacangan, umbiumbian, cacing, keong, ikan kecil dan pellet bahkan pada kondisi cherax yang telah moulting akan termakan oleh sesamanya. Ketiga perlakuan pemeliharaan pemberian pakan yang berbeda tidak berpengaruh nyata antara perlakuan namun mampu menekan terjadinya mortalitas yang tinggi. Hal tersebut diduga cherax mampu mencerna dan menyerap pakan dengan baik sehingga mampu menghasilkan energi yang sebagian digunakan untuk pertumbuhan dan ketahanan tubuhnya. Kandungan nutrisi pakan seperti protein, karbohidrat dan lemak berfungsi sebagai sumber energi (Ernawati et al., 2020).

Berdasarkan analisis uji tuckey menghasilkan pertumbuhan bobot dan panjang pada perlakuan pemberian pakan pellet berbeda nyata terhadap perlakuan pemberian pakan kelapa dan pellet + kelapa namun perlakuan pemberian pakan kelapa tidak berbeda nyata terhadap perlakuan pemberian pakan+kelapa. Sedangkan kelangsungan hidup pada perlakuan pemberian pakan pellet berbeda nyata antar perlakuan kelapa tapi tidak berbeda nyata antar perlakuan pellet + kelapa dapat dilihat pada tabel 2 .

Tabel 2. Hasil Uji Tuckey Pertumbuhan dan Kelangsungan Hidup Cherax quadricarinatus

\begin{tabular}{lccc}
\hline \multirow{2}{*}{ Perlakuan } & \multicolumn{3}{c}{ Pengamatan } \\
\cline { 2 - 4 } & Bobot (g/ekor) & Panjang (cm/ekor) & SR (\%) \\
\hline C1 : Pellet & $2,933 \pm 0,30^{\mathrm{c}}$ & $1,113 \pm 0,030^{\mathrm{c}}$ & $82,00 \pm 2,00^{\mathrm{ac}}$ \\
C2 : Kelapa & $4,133 \pm 0,11^{\mathrm{b}}$ & $1,220 \pm 0,034^{\mathrm{a}}$ & $86,67 \pm 3,05^{\mathrm{a}}$ \\
C3 : Pellet + Kelapa & $4,400 \pm 0,60^{\mathrm{ab}}$ & $1,186 \pm 0,115^{\mathrm{ab}}$ & $86,67 \pm 3,05^{\mathrm{ab}}$ \\
\hline
\end{tabular}

Keterangan : Huruf yang berbeda pada kolom yang sama menunjukkan perbedaan nyata antar perlakuan pada taraf $5 \%(0,05)$

Tabel 2. Memperlihatkan bahwa pertumbuhan bobot dan panjang tubuh tertinggi yaitu pada perlakuan pellet + kelapa yaitu sebesar 4,400 gram/ekor dan kelapa 1,220 gram/ekor. Hal ini diduga bahwa penggunaan pakan pellet telah menyediakan komposisi nutrisi yang lengkap dan tambahan buah kelapa yang memiliki kandungan protein dan beberapa jenis asam amino yang bermanfaat terhadap pertumbuhan. Ngampeerapong \& Chavasit, (2019) menyatakan bahwa daging kelapa memiliki kandungan 11 jenis asam amino dan makronutrien seperti protein, kadar air, lemak, karbohidrat dan Abu. Asam amino yang terdapat di dalam pakan mampu meningkatkan pertumbuhan dan efisiensi penggunaan pakan tanpa mengurangi kelangsungan hidup udang vaname (Rachmawati et al., 2020). Perlakuan penggunaan pakan kelapa tidak mudah menyebabkan perubahan kualitas air yang dapat menjadikan aktivitas lobster air tawar berkurang. Pakan tersebut bahkan sampai membusuk akan termakan oleh lobster air tawar, sehingga tidak menyebabkan kinerja hormone pertumbuhan menjadi terhambat. Masser \& Rouse (1997) menyatakan bahwa red claw bersifat detrivora omnivora yang lebih menyukai memakan tumbuhan dan hewan yang 
Buletin JSJ, 3 (1), 2021, 1-7

Available online di: http://ejournal-balitbang.kkp.go.id/index.php/JSJ/index

membusuk namus pada habitat aslinya sebagian besar terdiri dari bahan tanaman yang membusuk.

Tabel 1. memperlihatkan bahwa hasil uji tuckey terhadap kelangsungan hidup cherax pada perlakuan pemberian pakan berbeda diperoleh hasil tertinggi yaitu pada perlakuan pemberian kelapa dan pellet+kelapa masing-masing $86,67 \%$. Tingginya kelangsungan hidup selama penelitian pada setiap perlakuan diduga bahwa cherax mampu menekan terjadinya mortalitas yang tinggi. Hal tersebut dikarenakan pakan yang dikonsumsi menghasilkan energi yang sebagian digunakan untuk kelangsungan hidupnya. Fujaya (2004) menyatakan bahwa kandungan protein dan mineral akan bersama-sama air membentuk sel-sel di dalam tubuh sehingga mampu menjaga keseimbangan pengaturan asam basa, tekanan osmotik, cairan di dalam tubuh dan metabolisme ikan.

Data hasil pengukuran kualitas air seperti suhu, pH, oksigen terlarut (DO) dan amoniak pada media pemeliharaan benih cherax disajikan pada Gambar 1.

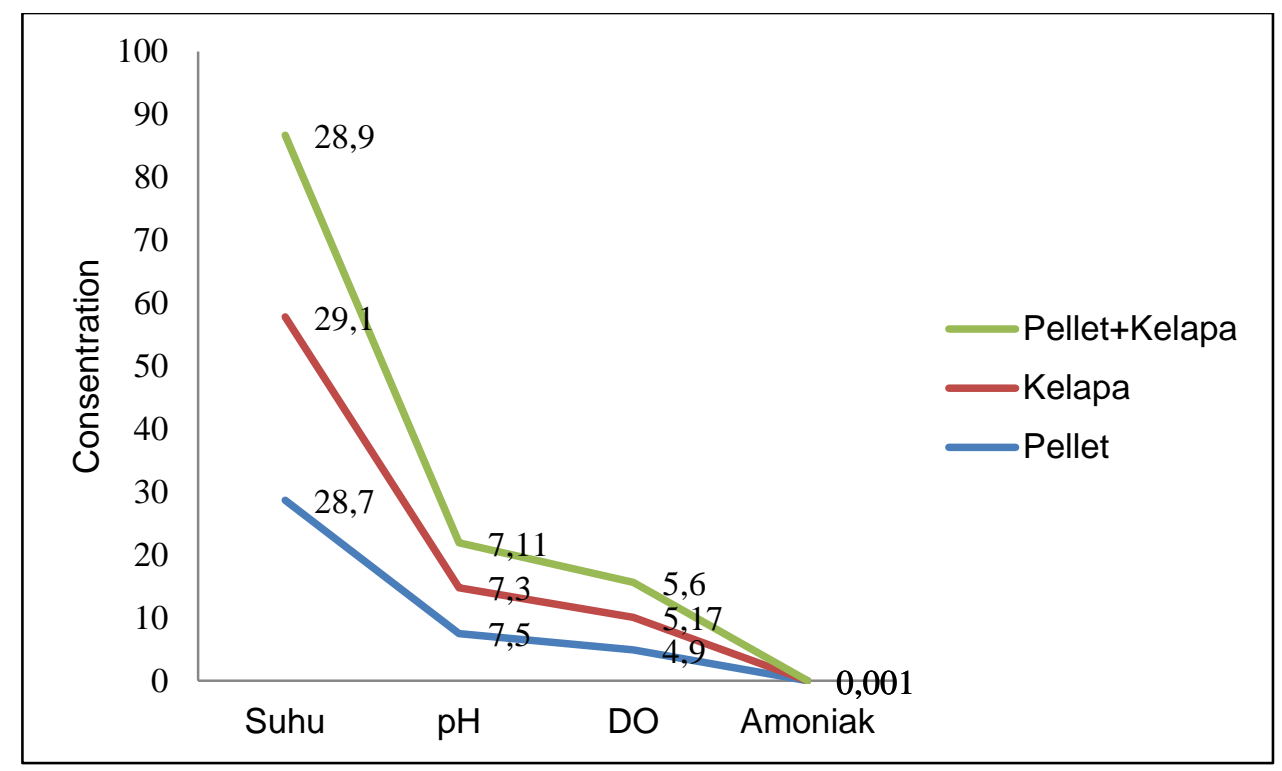

Gambar 1. Hasil Pengukuran Kualitas Air Media Pemeliharaan

Berdasarkan hasil pengukuran yang dilakukan pada media pemeliharaan pada ketiga perlakuan tersebut selama penelitian terjadi fluktuatif namun masih dalam batas kelayakan bagi kehidupan cherax (Gambar 1). Kondisi demikian tidak menyebabkan menurunnya pertumbuhan dan mortalitas yang tinggi. Terjadinya perubahan kualitas air biasanya dipengaruhi cuaca yang beruha-ubah, penggunaan jenis pakan dan sisa metabolisme hewan peliharaan. Kisaran suhu pada media pemeliharaan terhadap ketiga perlakuan tersebut yaitu $28,7-29,1^{\circ} \mathrm{C}$. Kisaran tersebut masih berada pada ambang batas dan sesuai dengan kebutuhan pertumbuhan cherax (Masser \& Rouse, 1997). Selama penelitian pH berada pada kisaran 7,5 - 7,11 pada media pemeliharaan. Konsentrasi tersebut tidak memperlihatkan pengurangan aktivitas hewan uji selama pemeliharaan. Hal serupa diungkapkan oleh (Sukmajaya \& Suharjo, 2003) bahwa pH 6,5 - 9 merupakan konsentrasi yang digunakan untuk pertumbuhan. Namun pada $\mathrm{pH} 4$ dan 11 merupakan death point terhadap ikan pada media pemeliharaan (Swingle, 1968). Konsentrasi $\mathrm{pH}$ yang dapat menyebabkan lobster air tawar mengalami kematian yaitu kurang dari 5 dan yang dapat mengurangi nafsu makan berkurang adalah pH 9 (Iskandar, 2003). Kisaran oksigen terlarut dan amoniak selama pemeliharan pada ketiga perlakuan penelitian tersebut tidak mengurangi nafsu makan dan aktifitas pergerakan lobster. Toleransi lobster air tawar terhadap kandungan oksigen terlarut bisa mencapai hingga 1,0 ppm dan amoniak hingga 1,0 ppm. Namun lobster air tawar akan tumbuh dengan baik pada habitat aslinya jika konsentrasi oksigen terlarut berada pada 
Buletin JSJ, 3 (1), 2021, 1-7

Available online di: http://ejournal-balitbang.kkp.go.id/index.php/JSJ/index

kisaran $>3-5 \mathrm{ppm}$ (Sukmajaya \& Suharjo, 2003). Jumlah oksigen terlarut pada media pemeliharaan dipengaruhi oleh kelancaran difusi dari udara ke dalam air. Konsentrasi amoniak yang optimal pada usaha produksi benih red claw yaitu $0,5 \mathrm{mg} / \mathrm{L}$ (Masser \& Rouse, 1997).

\section{KESIMPULAN DAN SARAN}

Penelitian yang telah dilakukan tentang pengaruh pakan berbeda terhadap kelangsungan hidup benih lobster air tawar dapat disimpulkan bahwa pertumbuhan bobot lobster air tawar tertinggi pada perlakuan pemberian pakan pellet + kelapa dan panjang tertinggi pada perlakuan pemberian kelapa saja dan kelangsungan hidup tertinggi yaitu pada perlakuan pemberian kelapa dan pellet + kelapa. Selama pemeliharaan kondisi kualitas air mengalami perubahan namun masih batas layak pemeliharaan.

Saran yang dapat diberikan adalah perlu dilakukan penelitian lanjutan tentang penggunaan berbagai jenis bahan-bahan nabati sebagai pakan lobster air tawar tanpa menggunakan pellet untuk mengurangi biaya pakan.

\section{DAFTAR PUSTAKA}

Ernawati, \& Hamsir. (2019). Bioenkapsulasi Karotenoid pada Skeletonema costatum dan Artemia Terhadap Pertumbuhan dan Kelangsungan Hidup Larva Nila Air Payau. VIII(2), 105-113. https://doi.org/10.1017/CBO9781107415324.004

Ernawati, Saddang, \& Irwan. (2020). Efektivitas $\beta$-Karoten pada Nauplius Artemia. Airaha, IX(2), 151-154. http://jurnalairaha.org/index.php/airaha/article/view/176/126

Fujaya, Y. (2004). Fisiologi Ikan. Dasar Pengembangan... -. PT.Rineka Cipta, Jakarta. https://scholar.google.com/scholar?hl=id\&as_sdt=0\%2C5\&q=Fujaya\%2C+Y.+\%282004 $\% 29 .+$ Fisiologi+lkan.+Dasar+Pengembangan+Teknik+Perikanan.+PT.+Rineka+Cipta\% $2 \mathrm{C}+$ Jakarta+Fegan\%2C\&btnG=

Huisman, E.A. 1976. Food convertion efficiencies at maintenance and production levels for carp Cyprinus carpio Linn. and rainbow trout Salmo gairdneri Rich. Aquaculture, 9 (2) : $159-273$

Iskandar. 2003. budidaya lobster air tawar. Jakarta: Penebar Swadaya.

Kakam, Y., Sulmartiwi, L., \& Al -Arif, M. A. (2008). Pemberian Pakan Yang Berbeda Terhadap Pertumbuhan Dan Rasio Konversi Pakan Lobster Air Tawar (Cherax quadricarinatus) Dengan Sistem Botol. 3(1), 282.

Karplus, I., Hapaz, S., Hulata, G., Segev, R., \& Barki, A. (2001). Culture Of Australian RedClaw Crayfish (Cherax quadricarinatus) In Israel. 53(1), 23-33.

Kwon, K., Park, K. H., \& Rhee, K. C. (1996). Fractionation and characterization of proteins from coconut (Cocos nucifera L.). Journal of Agricultural and Food Chemistry, 44(7), 1741-1745. https://doi.org/10.1021/jf9504273

Lengka, K., \& Kolopita, M. (2013). Teknik Budidaya Lobster (Cherax quadricarinatus) Air Tawar di Balai Budidaya Air Tawar (BBAT) Tatelu. E-Journal BUDIDAYA PERAIRAN, 1(1), 15-21. https://doi.org/10.35800/bdp.1.1.2013.726

Masser, M., \& Rouse, D. (1997). Australian red claw crayfish. Southern Regional Aquaculture Center, 244, 1-8. http://www.ca.uky.edu/wkrec/AustralianRedClaw.pdf

Ngampeerapong, C., \& Chavasit, V. (2019). Nutritional and bioactive compounds in coconut meat of different sources: Thailand, Indonesia and Vietnam. Chiang Mai University 
Buletin JSJ, 3 (1), 2021, 1-7

Available online di: http://ejournal-balitbang.kkp.go.id/index.php/JSJ/index

Journal of Natural Sciences, 18(4), 562-573. https://doi.org/10.12982/CMUJNS.2019.0037

Rachmawati, D., Sarjito, S., Anwar, P. Y., \& Windarto, S. (2020). Pengaruh Penambahan Asam Amino Lisin pada Pakan Komersil terhadap Efisiensi Pemanfaatan Pakan, Pertumbuhan, dan Kelulushidupan Udang Vaname (Litopenaeus vannamei). Jurnal Kelautan Tropis, 23(3), 388-396. https://doi.org/10.14710/jkt.v23i3.9183

Rodríguez-Canto, A., Arredondo-Figueroa, J. L., Ponce-Palafox, J. T., \& Rouse, D. B. (2002). Growth characteristics of the Australian redclaw crayfish, cherax quadricarinatus, cultured in an indoor recirculating system. Journal of Applied Aquaculture, 12(3), 59-64. https://doi.org/10.1300/J028v12n03_06

Sukmajaya, Y., \& Suharjo. (2003). Lobster Air Tawar komoditas Perikanan Prospektif. In Agromedia Pustaka.

https://scholar.google.com/scholar?hl=id\&as_sdt=0\%2C5\&q=Sukmajaya+Y\%2C+dan+S uharjo.+2003.+Lobster+air+tawar+komoditas+perikanan+prospektif.+Jakarta\%3A+Agro media+Pustaka.+\&btnG $=$

Supito., Kuntiyo., \& Djunaidah, I.S. (1998). Kaji pendahuluan pembesaran kerapu macan (Epinephelus fuscoguttatus) di Tambak. Prosiding seminar teknologi perikanan pantai Bali. Perkembangan terakhir teknologi budidaya pantai untuk mendukung pemulihan ekonomi nasional. Pusat Penelitian dan Pengembangan Perikanan Loka Penelitian Perikanan Pantai Gondol-Bali bekerjasama dengan Japan International Cooperation Agency JICA ATA. HIm.:25-32

Swingle, H. . (1968). Standardization of chemical analysis for waters and pond muds. F.A.O. Fish.

https://scholar.google.com/scholar?hl=id\&as_sdt=0\%2C5\&q=Swingle\%2C+H.+S.+\%28 1968\%29.+Standardization+of+Chemical+Analysis+for+Water+and+Pond+Muds.+F.+A. + O. + Fish\%2C+379-406.\&btnG=

Taufiq, M., Dewi, K. M. C., Handono, \& Rosidi, I. (2016). Pengaruh Pemberian Berbagai Jenis Pakan Terhadap Pertumbuhan Lobster Air Tawar ( Cherax quadricarinatus ) by Mohammad Tauf iq. Education and Human Development Journal, 01(01), 98-109.

Wickins, J. F., \& Lee, D. O. . C. (2002). Crustacean farming ranching and culture. Blackwell Science, Oxford, https://scholar.google.com/scholar?hl=id\&as_sdt=0\%2C5\&q=Wickins\%2C+J.+F.+and+ D. + O. '+C.+Lee.+2002.+Crustacean+farming+ranching+and+culture.+Blackwell+Scienc e\%2C+Oxford\%2C+UK\&btnG=

Zonneveld, N., Huisman, E., \& Boon, J. (1991). Prinsip-prinsip budidaya ikan. https://research.wur.nl/en/publications/prinsip-prinsip-budidaya-ikan 